\title{
Bacteriological Quality of Reclaimed Wastewater Used for Irrigation of Public Parks in the United Arab Emirates
}

\author{
Amna Salem Hazim Al Amimi, Munawwar Ali Khan, and Rania Dghaim
}

\begin{abstract}
Bacteriological quality of reclaimed wastewater used for irrigation of thirty public parks located in Dubai and Sharjah was evaluated. Bacterial contaminants (Escherichia coli, Salmonella, Shigella and Enterobacter aerogenes) were tested by membrane filtration technique using Bismuth Sulphite Agar (BSA) and Violet Red Bile Agar (VRBA) media. The results showed the presence of Salmonella, Shigella, E. coli, Entereobacter aerogenes and other unidentified bacterial species on various selective media with different occurrence rates. The most common type of bacteria observed on the BSA media were Shigella $(63 \%)$, E. coli $(30 \%)$, Salmonella $(10 \%)$ and a large percentage of unidentified bacteria $(97 \%)$. Whereas on VRBA media the most common bacteria detected were $E$. coli $(83 \%)$, unidentified bacteria $(76 \%)$ followed by Enterobacter aerogenes (70\%). The overall results obtained in the present study demonstrated that only $40 \%$ of the reclaimed wastewater samples examined complied with the local and widely accepted international standards of less than 1000 fecal coliforms $/ 100 \mathrm{~mL}$ for unrestricted irrigation. Further studies are recommended to determine the survival rate of Salmonella and other coliform group bacteria in the soil irrigated by reclaimed wastewater. In addition, detailed research should be conducted to establish the identity of Salmonella, Shigella (up to the species and sub-species level) and other unidentified bacteria which were detected in most of the reclaimed water samples.
\end{abstract}

Index Terms-Bacteriological quality, reclaimed wastewater, public parks.

\section{INTRODUCTION}

Over the past few decades, the United Arab Emirates (UAE) have witnessed a growing water stress resulting from the rapid population and industrial growth. Water stress in the UAE is related to water scarcity, deterioration of water quality due to industrial and agricultural activities, depletion of aquifers, and saline water intrusion [1]. The quantity of fresh water available in the UAE is very low and estimated at $34 \mathrm{~m}^{3} /$ inhabitant $/ \mathrm{yr}$, while the consumption is very high, with the UAE having the third highest freshwater consumption in the world [2]. The provision of fresh water supply to meet the country's domestic, agricultural and industrial needs became

Manuscript received October 10, 2013; revised December 10, 2013.

Amna Salem Hazim Al Amimi was with the Environmental Health major at the Department of Natural Science \& Public Health, Zayed University, Dubai, UAE. She is now with the Department of Environment, Health and Safety, National Oil Company (ENOC), Dubai, UAE (e-mail: amna.alamimi88@gmail.com).

Munawwar Ali Khan and Rania Dghaim are with Department of Natural Science and Public Health, College of Sustainability Sciences and Humanities, Zayed University, Dubai, P.O.Box: 19282, UAE (e-mail: Munawwar.Khan@zu.ac.ae; Rania.Dghaim@zu.ac.ae). one of the greatest challenges that face the UAE. Recycled water generated after wastewater treatment process plays an important role as a substitute for fresh water, saving the production of potable water, and contributing to the reduction of carbon footprint generated from the desalination process. Currently, wastewater in the UAE undergoes a tertiary treatment to reduce the concentration of bacteria and other chemical contaminants found in secondary treated effluent [3], [4]. The use of recycled water in the UAE, however, is limited to irrigation of landscape areas, parks and streets in major cities. The recycled water is not used for agricultural purposes, particularly due to concerns over health and environmental hazards, as well as public and social attitudes towards the use of crops irrigated by recycled or reclaimed wastewater [5]. Most of the recycled water is discharged into the sea. The discharge of unused recycled water to the environment, particularly to natural water bodies can also cause serious environmental problems such as eutriphication and algal blooms [6]. To ensure a high quality production of recycled water, it is important to develop a systematic monitoring of water quality both at the plant and the end point (i.e. irrigated soil).

The impact of recycled water quality on human health and the environment still hamper the sustainable use of recycled water. Among the issues associated with low quality recycled water are microbial pathogens [7]. The uncertainty about the health risks to an exposed population through wastewater irrigation practices because of the possible presence of enteric pathogenic organism is one of the major disadvantages of wastewater reuse. Pathogenic bacteria, parasites, and viruses are all found in sewage and may survive treatment processes [8].

Adequate operation of wastewater treatment facilities, scientific updating of reuse guidelines and launching public awareness campaigns are core factors for successful and sustainable large scale wastewater reuse schemes [9]. A study that assessed pathogens in reclaimed effluent used for industrial crop irrigation indicated a significant reduction in Salmonella, E. coli and other fecal coliform members after proper wastewater treatment [9]. On the other hand, another study has shown survival of different serotypes of Salmonella and increased resistance to antibiotics. It was suggested that conventional wastewater treatment decreases the number of pathogenic microorganisms, but does not completely eliminate them [10]. Bacteriological quality of the treated wastewater after the final stage of treatment is evaluated by the presence of total and fecal coliform bacteria. Total coliform is a group of bacteria commonly found in the environment and these bacteria are not likely to cause illness but their presence indicates that the water is contaminated by 
more harmful microorganisms. E. coli is one of the total coliform group members and its presence indicates the general bacteriological quality of water [11]. Several studies have indicated the survival of human pathogens in soils irrigated with recycled water [8], [12], [13]. The presence of pathogenic microorganisms in recycled water used for irrigation creates potential health hazards for the exposed human population [6], [14]. Therefore, prior to application in soil irrigation, recycled water should be treated to high quality to prevent transport of various pathogens through irrigated soils. Without some type of microbial monitoring, treatment requirements cannot adequately be assessed for performance and the more understanding of the risks posed microbial pathogens in recycled water will have greater public acceptance [15]. Uncontrolled use of reclaimed wastewater can have significant negative impacts on human health and the environment and these impacts can be minimized when good management practices are implemented [16].

Very little published data are available on the quality of reclaimed wastewater in the UAE. Bacteriological quality of reclaimed wastewater after the final stage of treatment should be carefully monitored before it is used for irrigation or other related activities. In general, there are several categories of very well maintained public parks in Dubai and Sharjah which are expanding due to extensive development and urbanization. These public parks are mostly irrigated by reclaimed wastewater therefore the risk of irrigated soil contamination by different types of pathogenic bacteria can increase in spite of using the advanced wastewater treatment methods including sand filtration and chlorination. Therefore, investigating the occurrence of different types of bacteria including Salmonella, Shigella, E.coli and other coliform bacteria in the irrigation water used in public parks is important to know whether the wastewater treatment methods utilized by the concerned municipalities are adequate to reduce the harmful bacteria. This study aimed at collecting preliminary data on the occurrence of a few bacterial species such as Escherichia coli, Salmonella, Shigella and Enterobacter aerogenes in the reclaimed wastewater used for irrigation of selected public parks in the emirates of Dubai and Sharjah.

\section{MATERIALS AND Methods}

In total, 30 public parks located in the emirate of Dubai and Sharjah were chosen randomly. Of these 30 public parks, 17 were located in the emirate of Dubai and 13 in the emirate of Sharjah. The reclaimed wastewater sampling was performed twice a week within a period of two months during April-May, 2011. Sterile bottles of 1 liter size were used for sample collection from the irrigation pipes (at the end point of water discharge) in each park. In total, 30 samples (one sample from each park) were collected and transported to the laboratory within 1-2 hours of sampling. The membrane filtration procedure was used to enumerate the bacterial species [17]. Appropriate volumes of water samples were filtered through $0.45 \mathrm{~mm}$ sterile filters (Sartorius, Germany). The quantitative analyses by membrane filtration technique were carried out in duplicate.
Culture media and incubation conditions used were: 1) Bismuth Sulfite Agar (BSA) (HiMedia, India) for Salmonella, Shigella, E. coli $\left(36^{\circ} \mathrm{C}, 24-48\right.$ hour); 2) Violet Red Bile Agar (VRBA) (HiMedia, India) for E. coli, Salmonella typhimurium and Enterobacter aerogenes (at $36^{\circ} \mathrm{C}, 24-48$ hours).

\section{RESULTS AND DISCUSSION}

The results of this study showed the occurrence of different types of bacteria in the reclaimed wastewater samples used for irrigation of various public parks located in Dubai and Sharjah. Salmonella, Shigella, E. coli, Entereobacter aerogenes and other unidentified bacteria were detected on BSA and VRBA media with different occurrence rates. Fig. 1 shows the overall percentage recovery of the four groups of bacteria detected in 30 reclaimed wastewater samples on the BSA media.

The results indicated that 6 out of 30 irrigation water samples $(20 \%)$ were positive for Salmonella species which formed black color colonies on the BSA media and 2 of these 6 samples were found to contain more than 1000 colonies of Salmonella per $100 \mathrm{ml}$ of the sample (i.e $>1000 \mathrm{cfu} / 100 \mathrm{ml}$ ). However, Salmonella in the remaining 4 irrigation water samples ranged between $1-3 \mathrm{cfu} / 100 \mathrm{ml}$. The occurrence of Salmonella in the raw and treated wastewater used for irrigation of grass has been reported earlier [9].

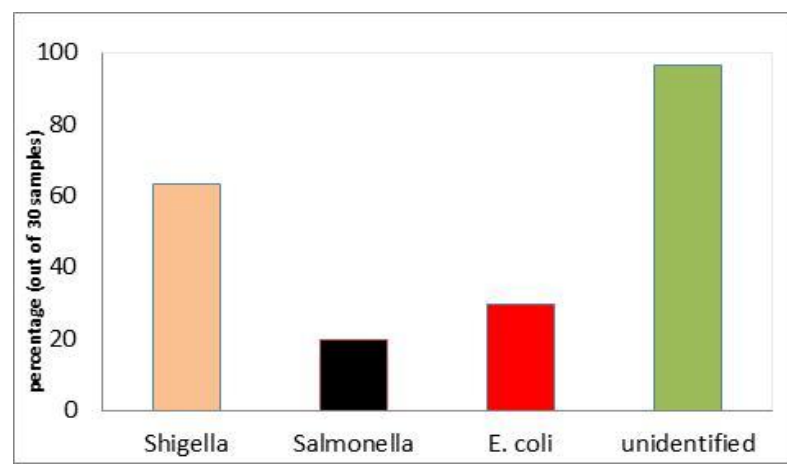

Fig. 1. Most common types of bacteria on the BSA media.

In a study that compared the microbial quality of wastewater before and after the treatment stages, results indicated the presence of a high number of coliform bacteria, worm eggs, and Salmonella in the raw wastewater whereas treated wastewater was free from coliform bacteria or Helminthes eggs [9]. However, in the present study reclaimed water from six public parks located in Dubai and Sharjah were found positive for Salmonella spp. Two of these public parks located in Sharjah were found to contain more than 1000 Salmonella colonies $/ 100 \mathrm{ml}$. The presence of Salmonella in the reclaimed water could be due to the effect of sanitary treatment method on the survival of the different serotypes of Salmonella as reported in a previous study [10]. Results also indicated that wastewater treatment might have an impact on the Salmonella increased resistance to antibiotics [10]. Table I and Table II show the bacteriological counting results for Dubai and Sharjah public parks respectively.Furthermore, Shigella species were predominantly observed in 19 out of total 30 reclaimed 
wastewater $(63 \%)$. Four of these nineteen samples were found to have Shigella in the range of $>50 \mathrm{cfu} / 100 \mathrm{ml}$, whereas 15 out of these 19 samples had Shigella in the range of $<50 \mathrm{cfu} / 100 \mathrm{ml}$ of the sample. Whereas, 9 out of 30 samples were found to contain E. coli $(30 \%)$ and of these 9 samples, only one had shown $E$. coli colony count of $1000 \mathrm{cfu} / 100 \mathrm{ml}$. A large number of unknown bacteria in the range of $3->1000 \mathrm{cfu} / 100 \mathrm{ml}$ were also detected in 29 out of 30 samples $(96 \%)$.

\begin{tabular}{cccccccc}
\multicolumn{2}{c}{ TABLE I: BACTERIAL COUNT IN THE RECLAIMED WASTEWATER } \\
\hline \hline $\begin{array}{c}\text { Duba } \\
i\end{array}$ & \multicolumn{3}{c}{$\begin{array}{c}\text { BSA media } \\
\text { (cfu/100ml)* }\end{array}$} & \multicolumn{3}{c}{$\begin{array}{c}\text { VRBA media } \\
\text { (cfu/100ml)* }\end{array}$} \\
\hline Park & Sal & Sh & EC & Un & EC & Et & Un \\
\hline D1. & 0 & 44 & 0 & 0 & 0 & 0 & 74 \\
D2. & 1 & 5 & 0 & 48 & 16 & 18 & 0 \\
D3. & 0 & 6 & 0 & 73 & 78 & 0 & 0 \\
D4. & 0 & 0 & tmtc & 61 & 50 & 0 & 0 \\
D5. & 0 & 5 & 0 & tmtc & 37 & 2 & 18 \\
D6. & 0 & 7 & 0 & tmtc & 0 & 65 & 50 \\
D7. & 0 & 4 & 0 & 3 & 72 & 0 & 2 \\
D8. & 0 & 0 & 62 & 4 & 0 & 35 & 45 \\
D9. & 0 & 0 & 52 & tmtc & tmtc & 53 & 35 \\
D10. & 0 & 16 & 0 & 7 & tmtc & 25 & 48 \\
D11. & 0 & 0 & 15 & tmtc & tmtc & 1 & 2 \\
D12. & 0 & 0 & 0 & tmtc & tmtc & 0 & 2 \\
D13. & 0 & 6 & 0 & 8 & 23 & 0 & 0 \\
D14. & 0 & 0 & 19 & tmtc & tmtc & 0 & 84 \\
D15. & 0 & 33 & 0 & 25 & tmtc & 14 & 22 \\
D16. & 47 & tmtc & 0 & tmtc & tmtc & 1 & 5 \\
D17. & 0 & 23 & 0 & 41 & 21 & 3 & 16 \\
\hline \hline
\end{tabular}

*cfu=colony forming unit; Sal=Salmonella; Sh=Shigella; EC=Escherichia coli; Un=unidentified bacteria; $\mathrm{Et}=$ Enterobacter aerogenes; tmtc (too many to count $)=>1000 \mathrm{cfu} / 100 \mathrm{ml}$

Fig. 2 indicates the overall percentage recovery of three groups of bacteria frequently observed in 30 samples on the VBRA media. For instance, examination of bacterial species growth on the VRBA media showed that 25 of the 30 reclaimed wastewater samples $(83 \%)$ contained $E$. coli. In 12 out of 30 samples $E$. coli were found in the range of $<100 \mathrm{cfu} / 100 \mathrm{ml}$, whereas 18 out of 30 samples detected $E$. coli in the range of more than $1000 \mathrm{cfu} / 100 \mathrm{ml}$. In addition, Enterobacter aerogenes colonies were also detected in 20 samples in the range of $3-65 \mathrm{cfu} / 100 \mathrm{ml}$. As in BSA media, a large number of unknown bacteria in the range of $3-78 \mathrm{cfu} / 100 \mathrm{ml}$ were also detected in 23 out of 30 samples (76\%) on the VRBA media.

In general, this investigation indicated that the majority of the tested reclaimed wastewater samples from public parks were contaminated with E. coli, Salmonella, Shigella, Enterobacter aerogenes and some unknown bacterial species.

Microbiological quality guidelines for treated wastewater use for irrigation are generally based on total coliforms, fecal coliforms, and/or Escherichia coli [13]. However, bacterial species such as Salmonella, Shigella and Enterobacter are not routinely monitored in the raw and treated wastewater. In this study we specifically targeted these bacteria in order to know their occurrences rate in the reclaimed wastewater. BSA media was used to detect Salmonella, Shigella whereas VRBA media was used to detect E. coli and Enterobacter. BSA media can support the growth of $E$. coli as well. But in this study we found that the recovery rate of E. coli on VRBA media was much higher than that of BSA media.

\begin{tabular}{cccccccc}
\multicolumn{2}{c}{ TABLE II: BACTERIAL COUNT IN THE RECLAIMED WASTEWATER } \\
\hline \hline Sharjah & \multicolumn{3}{c}{$\begin{array}{c}\text { BSA media } \\
\text { (cfu/100ml)* }\end{array}$} & \multicolumn{4}{c}{$\begin{array}{c}\text { VRBA media } \\
(\mathrm{cfu} / 100 \mathrm{ml}) *\end{array}$} \\
\hline Park & Sal & Sh & EC & Un & EC & Et & Un \\
\hline S1. & 1 & 76 & 0 & 5 & tmtc & 11 & 9 \\
S2. & 0 & 36 & 0 & 3 & tmtc & 38 & 42 \\
S3. & 0 & 0 & 0 & 4 & 12 & 0 & 0 \\
S4. & 0 & 24 & 0 & 1 & 0 & 7 & 0 \\
S5. & 0 & 127 & 0 & 4 & tmtc & 14 & 0 \\
S6. & 0 & 9 & 0 & 3 & tmtc & 21 & 4 \\
S7. & 0 & 131 & 18 & 3 & tmtc & tmtc & 9 \\
S8. & 0 & 0 & 14 & 48 & tmtc & 30 & 26 \\
S9. & tmtc & 0 & 0 & 1 & tmtc & 70 & 0 \\
S10. & 0 & 25 & 11 & 1 & tmtc & 35 & 10 \\
S11. & 0 & 0 & 16 & 107 & 0 & 61 & 24 \\
S12. & 20 & 0 & 0 & 46 & tmtc & 0 & 68 \\
S13. & tmtc & 0 & 0 & 1 & tmtc & 4 & 16
\end{tabular}

$* \overline{\mathrm{cfu}=\text { colony forming unit; Sal= Salmonella } ; \text { Sh=Shigella } ; \mathrm{EC}=\text { Escherichia }}$ coli; $\mathrm{Un}=$ unidentified bacteria; $\mathrm{Et}=$ Enterobacter aerogenes; tmtc (too many to count $)=>1000 \mathrm{cfu} / 100 \mathrm{ml}$

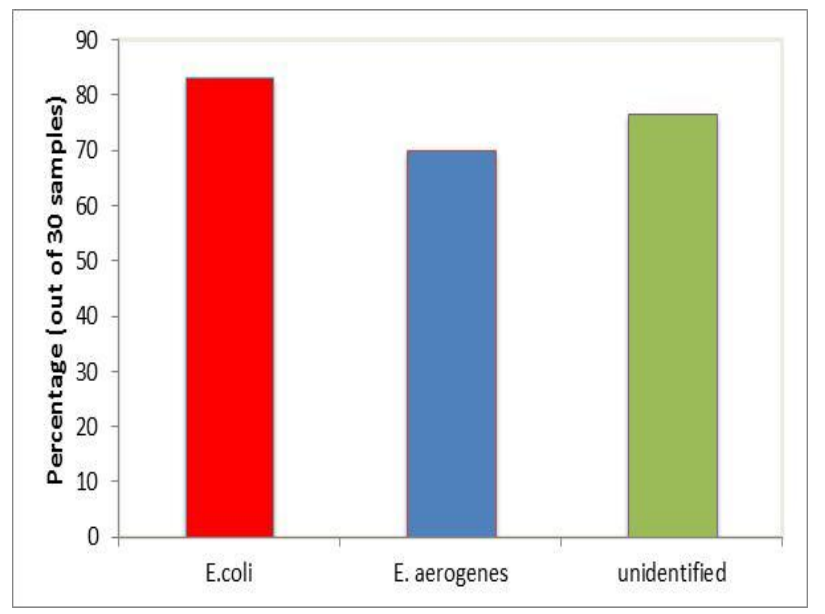

Fig. 2. Most common types of bacteria on the VRBA media.

The universal application of bacterial standards for water quality assessment will not yield the same risks from microbial pathogens in reclaimed wastewater around the world [15]. It is important that risk posed by specific bacterial species be evaluated in the reclaimed wastewater by performing detailed microbial risk assessment as suggested by a previous study [15]. Collecting more samples from several locations within the parks like reservoir tank inlet and outlet points, and the source (Wastewater treatment plant) of reclaimed water could give more precise results. It is important that concerned authorities take the necessary 
actions to prevent the risks of pathogenic bacteria contamination of reclaimed water used for irrigation of public parks in the UAE. Additionally, assessment of the microbial quality of reclaimed water on a regular and long term basis and examination of the survival rate of important pathogenic microorganisms are essential to ensure the safe use of reclaimed wastewater for irrigation purposes.

\section{CONCLUSION}

In conclusion, bacteriological quality of treated wastewater used for irrigation of public parks in Dubai and Sharjah was evaluated for the presence of Salmonella, E. coli and other coliform group bacteria. The results of this study showed a high occurrence of coliform group bacteria in $60 \%$ of the reclaimed wastewater samples which exceeded the local and widely accepted international standard of more $1000 \mathrm{cfu} / 100 \mathrm{ml}$ for unrestricted irrigation. Further studies are recommended to determine the survival rate of Salmonella and other coliform group bacteria in the soil or the grass/ plants which are irrigated by the reclaimed wastewater. In addition, detailed research should be performed to establish the identity of Salmonella (up to the species and sub-species level) and other unidentified bacteria which were detected in most of the collected samples.

\section{ACKNOWLEDGMENT}

The authors would like to thank Dubai and Sharjah municipality for irrigation water sampling related assistance. We thank Saniyah Khan from the University College, Zayed University, Abu Dhabi, UAE for providing valuable tips for the improvement of the manuscript.

\section{REFERENCES}

[1] Z. S. Rizk and A. S. Alsharhan, "Water Resources in the United Arab Emirates," in Water Resources Perspectives, Management and Policy. A. A. Alsharhan Ed., Amsterdam, Netherlands: Elsevier Science, 2003 , pp. 245-264.

[2] World Bank. (2007). Making the most of scarcity: accountability for better water management results in the Middle East and North Africa. Washington D.C. [Online]. Available: https://openknowledge.worldbank.org/handle/10986/6845

[3] A. Al Ajmi, A. Salih, A. A. Kadim, and I. Y. Othman, "Chemical constituents and heavy metals contents of barley fodder prduced under hydroponic system in GCC countries using tertiary treated sewage effluents," Journal of Phytology, vol. 1, no. 6, pp. 374-380, 2009.

[4] A. Al-Turki, "Assessment of effluent quality of tertiary wastewater treatment plant at buraidah city and its reuse in irrigation," Journal of Applied Sciences, vol. 10, no. 16, pp. 1723-1731, 2011.

[5] W. Al-Zubari, "Towards the establishment of a total water cycle management and re-use program in the GCC countries," Desalination, vol. 120, pp. 3-14, 1998.

[6] S. Toze, "Water reuse and health risks real vs. perceived," Desalination, vol. 187, pp. 41-51, 2006.

[7] M. E. Gemmell and S. Schmidt, "Potential links between irrigation water quality and microbiological quality of food in subsistence farming in Kwazulu-Natal, South Africa," in Technology and Education Topics in Applied Microbiology and Microbial Technology, A. Méndez-Vilas Ed. Formatex Research Center: Badajoz, Spain, 2010 vol. 2, pp. 1190-1195.

[8] G. M. Pablo, "Microbiological water quality in irrigation water, treated watewater, and untreated wastewater and its impact on vegetabels in
Sonora, Mexico," Ph.D. dissertation, Dept. Soil, Water \& Environmental Science, Univ. of Arizona., Tucson, 2007.

[9] R. Al-Sa'ed, "Pathogens assessment in reclaimed effluent used for industrial crops irrigation," International Journal of Environmental Research and Public Health, vol. 4, pp. 68-75, 2007.

[10] E. Espigares, A. Bueno, M. Espigares, and R. Gálvez, "Isolation of salmonella serotypes in wastewater and effluent: effect of treatment and potential risk," International Journal of Hygiene and Environmental health, vol. 206, pp. 103-107, 2006.

[11] Governement of Saskatchewan. (2008 July). Coliform bacteria (for private water and health regulated public water supplies). [Online]. Available:

http://www.saskh2o.ca/PDF-WaterCommittee/ColiformBacteria.pdf

[12] K. Khashiboun, A. Zilberman, A. Shaviv, J. Starosvetsky, and R. Armon, "The fate of cryptosporidium parvum oocysts in reclaimed water irrigation-history and non-history soils irrigated with various effluent qualities," Water Air Soil Pollut, vol. 185, pp. 33-41, 2007.

[13] J. E. T. Mclain and C. F. Williams, "Assessing environmental impacts of treated wastewater through monitoring of fecal indicator bacteria and salinity in irrigated soils," Environ Monit Assess, vol. 184, pp. 1559-1572, 2012

[14] M. C. Alonso, L. P. C. Dionisio, A. Bosch de M. Pereira, B. S. Garcia-Rosado, and E. J. J. Borrego, "Microbiological quality of reclaimed water used for golf courses' irrigation," Water Science \& Technology, vol. 54, pp. 109-117, 2006.

[15] C. P. Gerba, and J. B. Rose, "International guidelines for water recycling: microbiological considerations," Water Science and Technology: Water Supply, vol. 3, no. 4, 311-316, 2003.

[16] M. Qadir, A. Bahri, and T. S. E. Al-Karadsheh, "Wastewater production, treatment, and irrigation in Middle East and North Africa," Irrig. Drainage Syst., vol. 24, pp. 37-51, 2010.

[17] Standard Methods for the Examination of Water and Wastewater, 20th ed., APHA, Washington D.C., 1998.

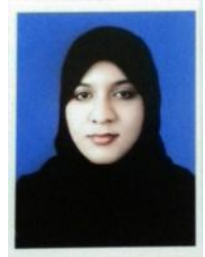

Amna Salem Hazim Alamimi is working as an industrial hygienist for Emirates National Oil Company (ENOC) group in the Environment, Health and Safety (EHSQ compliance department), Dubai, UAE. She received her B.Sc. Degree in the field of Environmental Health from Zayed University, Dubai, United Arab Emirates.

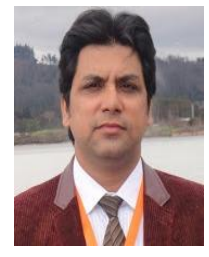

Munawwar Ali Khan is an associate professor in the Department of Natural Science and Public Health, College of Sustainability Sciences \& Humanities at Zayed University, Dubai, United Arab Emirates. He received his Ph.D in 2001 in the area of Environmental Engineering from the Department of Urban Engineering at University of Tokyo, Japan. His research work is in the general area of environmental microbiology and

biotechnology.

His specific focus is on developing and applying in situ (direct) molecular biological methods to detect microbial contaminants in water, wastewater, reclaimed, recreational water, food and clinical samples. He is also working on characterization of the microbial communities (including antibiotic resistance in microorganisms of public health relevance) in food, water and wastewater systems.

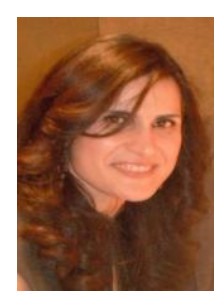

Rania Dghaim is an assistant professor in the Department of Natural Science and Public Health, College of Sustainability Sciences \& Humanities at Zayed University, Dubai, United Arab Emirates. She received her Ph.D. in Organomatallic Chemistry in 2000 from McGill University, Canada. Her research experience involved the development of new methodologies for the synthesis of biologically relevant molecules with pharmaceutical applications. Her current research is focused on environmental pollution, in particular, examining the chemical and microbial quality of water, soil and sediments. 